\title{
EARLY STAGES OF LIGNITE FORMATION IN PTOLEMAIS BASIN: A COAL-PETROGRAPHIC APPROACH
}

Siavalas G., Tsompanidou E., Kalaitzidis S., Bouzinos A. and Christanis K. Section of Earth Materials, Department of Geology, University of Patras, 26500 Rio-Patras s.kalaitzidis@upatras.gr, a.mpouzinos@upatras.gr, christan@upatras.gr

\section{ABSTRACT}

With the present study it is intended to assess the depositional palaeoenvironment of the lower part of the Lignite-bearing Sequence in the Ptolemais Basin, and more specifically in the areas of Notio-Field and Tomeas- 6 open pits. The sediments under study represent the seam between the Volcanic Tephra Layer and the Basal Marl, which constitute the roof and the floor, respectively.

Coal-petrographic results showed that Huminite is the main maceral group (84-96\%), while macerals from Liptinite and Inertinite groups display low values $(<10 \%)$. In bulk lignite samples the main mineral phases are quartz, calcite, clay minerals and feldspars, while in the ashes the main phases are quartz, anhydrite and lime.

The palaeoenvironment of the lignite formation was reconstructed using the lithological, coalpetrographic and mineralogical data, as well as coal-facies diagrammes. In Notio-Field Mine, at the early stages of lignite formation the conditions used to be limnotelmatic, while in Tomeas- 6 Mine they were telmatic. Upwards the conditions turned to more telmatic in both mine areas. The vegetation was mainly herbaceous with some arboreal elements occurring mostly in Tomeas- 6 area. The water influx was generally intense resulting in enhanced inorganic input.

\section{INTRODUCTION}

Coal petrography is one of the most prevailing methods for determining the palaeoenvironment of lignite formation. During the last decades many lignite deposits in Greece have been studied using this method (e.g. Cameron et al. 1984, Kaouras et al. 1991, Antoniadis et al. 1992, Kalaitzidis et al. 1998, Georgakopoulos \& Valceva 2000, Kalaitzidis \& Christanis 2000, Kalaitzidis et al. 2000, Papanicolaou et al. 2000, Kalaitzidis et al. 2001).

The Neogene basin of Ptolemais is the main energy centre of the country hosting about $4 \mathrm{Gt}$ of lignite, which occurs in form of thin layers alternating with inorganic sediments.

The aim of this study is to assess the depositional conditions at the early stage of lignite formation in Ptolemais Basin. This stage corresponds to the seam lying between the Volcanic Tephra Layer (known as "Characteristic Sand") and the "Basal Marl" that underlies the lignite deposit and forms the floor of the Lignite-bearing Sequence. The study is focused on the open pits of NotioField and Tomeas-6.

\section{GEOLOGICAL SETTING}

The Ptolemais Basin is part of the tectonic trench that extends from Prilep (Former Yugoslavian Republic of Macedonia) to Servia (Greece) with a general NNW-SSE direction. The basement of the basin consists of Palaeozoic and Mesozoic metamorphic and plutonic rocks underlying Cretaceous limestone and flysch (Pavlides \& Mountrakis 1987). The basement rocks are parts of the Pelagonic and Axios zones. Normal faults trending NW-SE and NNW-SSE that formed from Middle to Upper Miocene, are responsible for the formation of the basin (Pavlides \& Mountrakis 1987).

The sediments filling the basin are mainly limnic marls and clays that host the lignite seams. Thin Quaternary terrestrial deposits overlay these sediments. The whole sedimentary sequence formed from Upper Miocene to Holocene and is distinguished in the Lower Member, the Lignitebearing Sequence and the Upper Member (Anastopoulos \& Koukouzas 1972, Steenbrink 2001). 


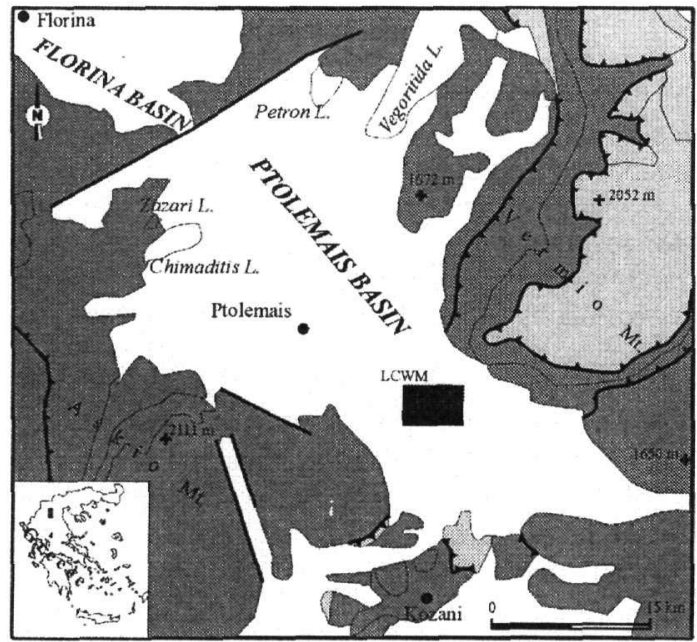

Pelagonic Overthrust Nappe and Plutonic Rocks

$\square$ Axios Geotectonic Zone

$\square$ Neogene-Tertiary sediments

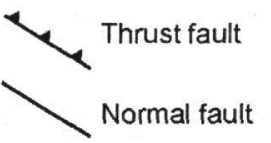

LCWM: Lignite Centre of West Macedonia

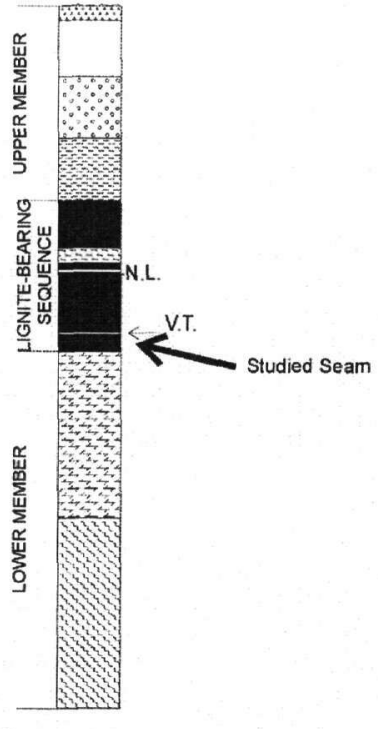

Alluvial fan deposits

Red-grey clays and conglomerates Yellow-grey clastic sediments Green-grey clayey marls

Intermediate spoil sediments

Alternation of lignite and inorganic sediments

Clayey marl

[3ु Sandy clay

N.L. Neritina layer

V.T. Volcanic tephra

Figure 1. Schematic geological map of the Ptolemais Basin (Kilias \& Mountrakis 1989) and lithologic column of the Ptolemais Formation (A.nastopoulos \& Koukouzas 1972).

\section{METHODOLOGY}

Samples were collected using channel sampling from the Notio-Field and Tomeas-6 Mines of the Lignite Centre of West Macedonia (LCWM). At both sites, the lithological features were macroscopically described and the lignite lithotypes were determined according to guidelines established by the International Committee for Coal and Organic Petrology (I.C.C.P. 1993).

Laboratory examinations included moisture and ash content determination of the lignite samples according to ASTM D3302-89 and D3174-89 methods, respectively. Based on these results and the macroscopical description, 20 samples from Notio-Field Mine and 21 samples from Tomeas- 6 Mine were chosen for coal-petrographic analysis. Polished blocks $(\varnothing 3 \mathrm{~cm})$ were prepared according to ASTM D2797-90 and examined using a Leica DMRX microscope. Point counting for maceral analysis (500 counts) was conducted under both white reflected light and blue-light excitation following the Stopes-Heerlen terminology (I.C.C.P. 1963, I.C.C.P. 1971, Taylor et al. 1998, I.C.C.P. 2001, Sýkorová et al. in prep).

Semi-quantitatively mineralogical analysis of the fine-powdered bulk lignite samples were carried out using a PHILIPS PW1050 X-ray diffractometer. The scanning area covered the interval $2 \theta$ $3-60^{\circ}$, with a scanning step of $0.02^{\circ}$ and a step time of $1 \mathrm{~s}$. 


\section{RESULTS}

\subsection{Macroscopical description}

The studied stratigraphic sequence represents the lower part of the Lignite-bearing Sequence and more specifically includes the layers that deposited between the Volcanic Tephra Layer and the Basal Marl (Fig. 1). The total thickness of this sequence ranges between 14 and $15 \mathrm{~m}$. In both, Notio-Field and Tomeas-6 Mines, the sequence is characterized by alternating thin lignite, clay and marl layers (Fig. 2). The thickness of lignite beds ranges from 2 to $115 \mathrm{~cm}$ (30 cm in average), while this of marl and clay layers from 3 to $25 \mathrm{~cm}$ (10 cm in average). Upwards, especially at Tomeas 6 Mine the lignite beds become thicker, whereas intercalations of inorganic layers are also less frequent.

Matrix lignite is the dominant lithotype along the studied profiles, although the xylite-rich lithotype occurs also in relatively high percentages, mostly at Tomeas-6 Mine. The lignite is light to dark brown, rich in plant remnants and bears fossils. The inorganic sediments consist almost exclusively of grey clays and yellow to white marls. They are rich in plant remnants and bear high amounts of fossils. The general direction of the layers is NE-SW and they dip from $5^{\circ}$ up to $17^{\circ} \mathrm{NW}$.
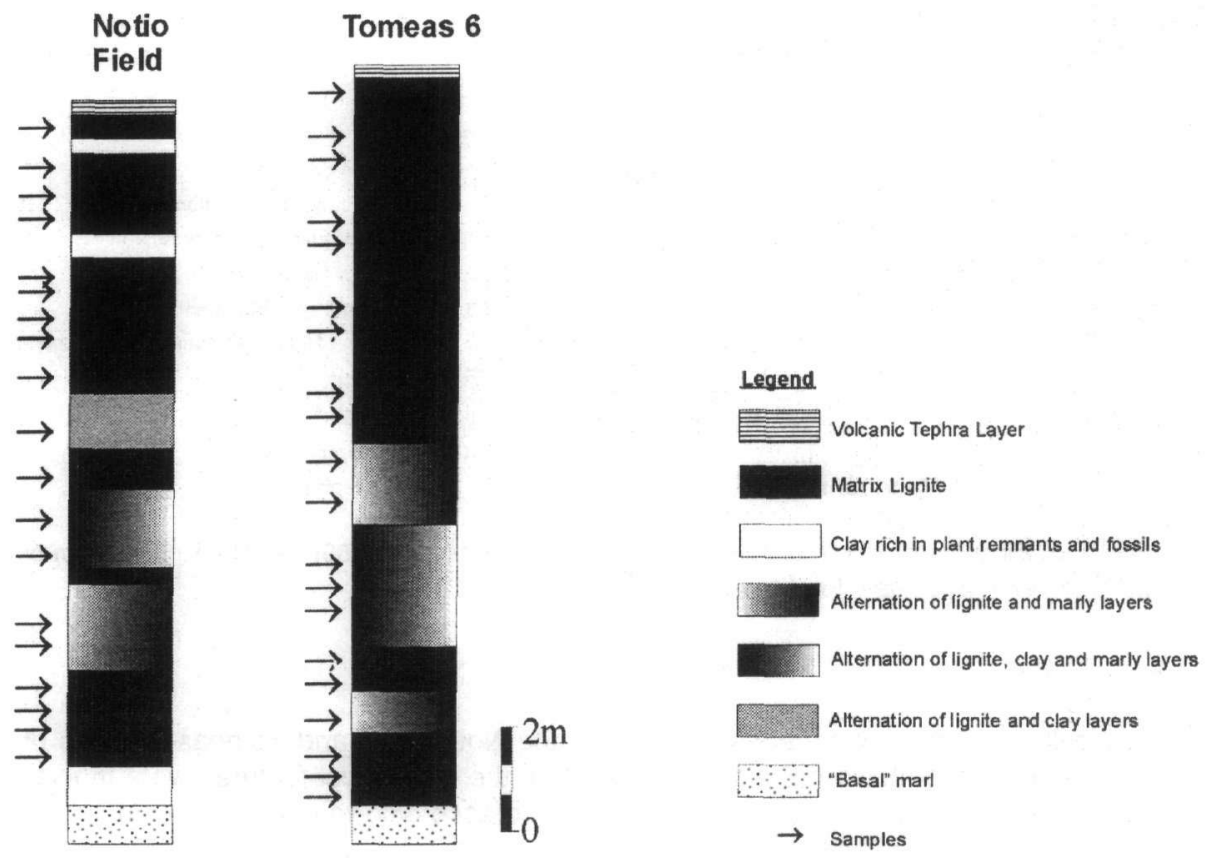

Figure 2. Lithologic columns of the lower part of the Lignite-bearing Sequence and sampling scheme.

\subsection{Proximate analysis}

Proximate analysis was carried out on 62 samples from Notio-Field and 53 samples from Tomeas-6 Mine. In Notio-Field samples, moisture varies from 34.6 to $73.5 \%$ with an average of $56.9 \%$. The dry ash content ranges from 6.8 to $51.9 \%$ (20\% in average). In Tomeas-6 samples, moisture ranges from 36.7 to $69.7 \%$ (61.7\% in average) and the dry ash content from 7.8 to $49.2 \%$ (16.4\% in average).

\subsection{Maceral analysis}

The results of maceral analysis are summarized in table 1. Huminite is the dominant maceral group in both mines with values from 84 to $96 \%$. Liptinite and inertinite contents are relatively low $(<10 \%)$. 
In Notio-Field samples, detrohuminite is the dominant maceral subgroup with an average content of $45.6 \%$, while telohuminite appears with an average of $41.65 \%$. On the contrary, at Tomeas- 6 Mine telohuminite is the main subgroup with average content $54 \%$. In both Notio-Field and Tomeas6 Mines, the dominant maceral is densinite with values up to $36 \%$ and $27.7 \%$, respectively. The macerals of gelohuminite subgroup occur in relatively low percentages $(<10 \%)$, with levigelinite being the most common. The higher detrohuminite percentages in samples from Notio-Field suggest that mechanical degradation of organic matter was more intense than in Tomeas-6, either due to increased activity of vital decomposers or due to relatively greater accumulation of friable phytogenic matter.

Liptinite group occurs with low percentages in both mines and with no specific variations. The average liptinite content for Notio-Field samples is $6 \%$ and for Tomeas- 6 samples is $5.7 \%$. The most common macerals are cutinite and liptodetrinite.

Table 1. Results of maceral analysis (in vol.-\%, on dry and mineral-free basis; mineral matter content in vol.-\%, on dry basis) and coal-petrographic indices and ratios.

\begin{tabular}{|c|c|c|c|c|c|c|}
\hline \multirow[b]{2}{*}{ Maceral } & \multicolumn{2}{|c|}{ NOTIO FIELD } & \multirow[b]{2}{*}{ Mean } & \multicolumn{2}{|c|}{ TOMEAS 6} & \multirow[b]{2}{*}{ Mean } \\
\hline & Min. & Max. & & Min. & Max. & \\
\hline Textinite A & & & & 0 & 1 & 0.2 \\
\hline Textinite B & 0 & 1 & 0.5 & 0 & 10 & 1.0 \\
\hline Texto-ulminite A & 2 & 13 & 5.6 & 4 & 30 & 11.4 \\
\hline Texto-ulminite B & 9 & 34 & 20.5 & 14 & 30 & 22.2 \\
\hline Eu-ulminite A & 1 & 12 & 6.5 & 3 & 20 & 9.3 \\
\hline Eu-ulminite B & 2 & 15 & 8.9 & 4 & 22 & 11.2 \\
\hline TELOHUMINITE & 24 & 60 & 41.7 & 37 & 72 & 54.0 \\
\hline Attrinite & 1 & 22 & 9.8 & 1 & 18 & 6.5 \\
\hline Densinite & 22 & 56 & 36.2 & 13 & 44 & 27.7 \\
\hline DETROHUMINITE & 30 & 61 & 45.6 & 18 & 52 & 33.9 \\
\hline Levigelinite & 1 & 5 & 2.7 & 1 & 4 & 1.8 \\
\hline Porigelinite & 0 & 1 & 0.1 & 0 & 1 & 0.1 \\
\hline Corpogelinite & 0 & 1 & 0.1 & & & \\
\hline GELOHUMINITE & 1 & 6 & 2.9 & 1 & 4 & 1.9 \\
\hline HUMINITE & 85 & 95 & 90.1 & 82 & 95 & 90.0 \\
\hline Fusinite & 0 & 3 & 1.0 & 0 & 4 & 1.0 \\
\hline Semi-fusinite & 0 & 1 & 0.4 & 0 & 1 & 0.3 \\
\hline Funginite & 0 & 1 & 0.1 & & & \\
\hline Inertodetrinite & 0 & 6 & 2.5 & 0 & 7 & 3.6 \\
\hline INERTINITE & 0 & 9 & 4.0 & 0 & 11 & 4.9 \\
\hline Sporinite & 0 & 1 & 0.1 & 0 & 1 & 0.2 \\
\hline Cutinite & 1 & 6 & 3.1 & 1 & 4 & 2.2 \\
\hline Suberinite & & & & 0 & 1 & 0.1 \\
\hline Alginite & 0 & 2 & 0.7 & 0 & 2 & 0.5 \\
\hline Liptodetrinite & 1 & 5 & 2.3 & 1 & 5 & 2.8 \\
\hline LIPTINITE & 3 & 9 & 6.1 & 4 & 9 & 5.7 \\
\hline Mineral matter & 2 & 24 & 6.5 & 2 & 20 & 6.6 \\
\hline A & 25 & 64 & 44.8 & 38 & 75 & 56.4 \\
\hline B & 33 & 70 & 51.2 & 22 & 56 & 39.1 \\
\hline C & 0 & 9 & 3.9 & 0 & 15 & 5.8 \\
\hline TPI & 0.4 & 1.8 & 0.9 & 0 & 3 & 1.5 \\
\hline GI & 2.2 & 23.3 & 8.6 & 2.8 & 23 & 9.6 \\
\hline GWI & 0.4 & 2 & 0.9 & 0.3 & 1.1 & 0.6 \\
\hline VI & 0.3 & 1.6 & 0.8 & 0.7 & 3.1 & 1.6 \\
\hline
\end{tabular}

Inertinite contents are low with average values 4.0 and $4.9 \%$ for Notio-Field and Tomeas-6 Mines, respectively. Inertodetrinite and fusinite are the most common macerals of this group.

The inorganic content determined during the microscopical observation greatly varies from 1.6 to $24.3 \%$. The most frequent minerals were carbonates (mainly calcite) that indicate authigenic sedimentation, clay minerals that indicate clastic sedimentation, and pyrite in form of framboids that indicates bacterial activity - 


\subsection{Mineral matter}

As already mentioned, mineral matter determinations were performed using $X$-ray diffraction on bulk lignite samples ana their ashes $\left(750^{\circ} \mathrm{C}\right)$. The identification of minerals present with low values in bulk lignite samples is difficult, because of the high noise/signal ratio due to the presence of organic matter.

The mineral phases determined in all the samples are shown in table 2. Quartz and calcite are the main minerals in the bulk samples, indicating clastic and authigenic sedimentation, respectively. Clay minerals display higher values in the Notio-Field than in the Tomeas- 6 samples. Other minerals present are feldspars, gypsum (mostly in Tomeas-6), aragonite, micas and pyrite. The latter mineral appears under the microscope in form of framboids.

The main mineral phases that were recognized in the ashes are quartz, anhydrite and lime, and to a less extent feldspars and clay minerals (Tab. 2). Anhydrite and lime are secondary phases, deriving from thermal breakdown of gypsum and calcite, respectively. On the contrary, quartz and feldspars remain intact, while hematite obviously derives from pyrite during combustion. Baryte and apatite were also determined in the ashes.

Table 2. Mineral phases determined from X-ray diffraction patterns of bulk and oxidized $\left(750^{\circ} \mathrm{C}\right.$ ashes) lignite.

\begin{tabular}{|c|c|c|c|c|c|c|c|c|c|c|c|c|c|c|}
\hline Sample & Mineral & $\begin{array}{l}\frac{\mathrm{N}}{\mathrm{V}} \\
\text { 夏 }\end{array}$ & 志 & 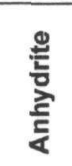 & 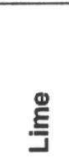 & 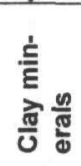 & $\begin{array}{l}\frac{n}{00} \\
\frac{0}{0} \\
\frac{0}{0} \\
\frac{1}{0}\end{array}$ & $\begin{array}{l}\text { E } \\
\text { ․ㅡㄹ } \\
\text { 일 }\end{array}$ & 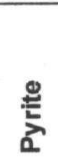 & 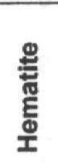 & 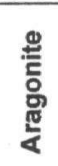 & 总 & 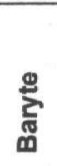 & 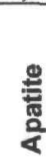 \\
\hline \multirow{2}{*}{$\begin{array}{l}\text { Notio } \\
\text { Field }\end{array}$} & $\begin{array}{c}\text { Bulk } \\
\text { Sample }\end{array}$ & ++ & +++ & & & + & ++ & + & + & & + & & & \\
\hline & $\begin{array}{c}\text { Ash } \\
750^{\circ} \mathrm{C}\end{array}$ & +++ & + & +++ & +++ & ++ & +++ & & & + & + & + & + & + \\
\hline \multirow{2}{*}{$\begin{array}{c}\text { Tomeas } \\
6\end{array}$} & $\begin{array}{c}\text { Bulk } \\
\text { Sample }\end{array}$ & +++ & +++ & & & ++ & + & ++ & ++ & & + & + & & \\
\hline & $\begin{array}{c}\text { Ash } \\
750^{\circ} \mathrm{C}\end{array}$ & +++ & ++ & +++ & +++ & & & & & ++ & & + & & ++ \\
\hline
\end{tabular}

\section{COAL-FACIES DIAGRAMMES}

Maceral ratios (Tab. 1) and coal-facies diagrammes (Fig. 3) are used to interpret the palaeoenvironment of lignite formation and the dominant conditions at the palaeomires. However, the coalfacies diagrammes have to be evaluated in combination with geological and lithostratigraphical data, as well as maceral distribution and mineralogical results. Otherwise, the results can be easily misinterpreted (Scott 2002).

The ternary diagramme proposed by Mukhopadhyay (1989) shows that all the samples are plotted within the area that indicates wet and reducing conditions during peat accumulation. This prevented the oxidation of the organic matter and the formation of inertinite. Comparing the results it seems that in Notio-Field the conditions were more destructive concerning the organic matter and that peat accumulation took place under increased maceration. It is also shown that the vegetation was mainly herbaceous, although in Tomeas-6 area arboreal elements were also common.

The TPI vs. GI diagramme proposed by Diesel (1992) is used to assess the palaeoenvironment of peat formation. The tissue preservation index (TPI) is a measure of humification grade of the initial organic matter and is defined as the ratio of the structured to the structureless macerals.

$\mathrm{TPI}=\frac{\text { Telohuminite }+ \text { Corpogelinite }+ \text { Fusinite }}{\text { Attrinite }+ \text { Densinite }+ \text { Gelinite }+ \text { Inertodetrinite }}$

The gelification index $(\mathrm{GI})$ is used to determine the moisture conditions of the peatland and is defined as the ratio of the gelified macerals to the non-gelified macerals. The GI and TPI are used in the present study as they are proposed by Kalaitzidis et al. (2004).

$$
\mathrm{GI}=\frac{\text { Ulminite }+ \text { Gelohuminite +Densinite }}{\text { Textinite }+ \text { Attrinite + Inertinite }}
$$


The TPI vs. GI diagramme shows that the plant remnants were better conserved in Tomeas-6 Mine. The lignite layers of the lower part of the sequence, in both mines, were formed under limnotelmatic conditions, while some of the upper part layers deposited in a telmatic regime and probably originated from arboreal vegetation, particularly at the area of Tomeas-6 palaeomire.

The VI vs. GWI diagramme is used to classify peat-forming environments according to their hydrological regime and especially the inflow of nutrients into the peatland (Calder et al. 1991). In this study both the $\mathrm{VI}$ and $\mathrm{GWI}$ indices are used as proposed by Kalaitzidis et al. (2004).

The groundwater influence index $(\mathrm{GWI})$ is a measure of the moisture conditions.

$$
\mathrm{GWI}=\frac{\text { Gelohuminite }+ \text { Densinite }+ \text { Mineral Matter }}{\text { Telohuminite + Attrinite }}
$$

The vegetation index (VI) depends on the peat-forming plant species. It is defined as the ratio of macerals derived from arboreal vegetation to these derived from herbaceous vegetation.

$$
\mathrm{VI}=\frac{\text { Telohuminite }+ \text { Fusinite }+ \text { Semifusinite }+ \text { Cutinite }+ \text { Sporinite }+ \text { Suberinite }+ \text { Resinite }}{\text { Detrohuminite }+ \text { Inertodetrinite }+ \text { Other Liptinites }}
$$

The VI vs. GWI diagramme suggests that initially peat-forming conditions were limnotelmatic and gradually became pure telmatic (Fig. 3). The GWI values of the Notio-Field samples indicate rheotrophic to mesotrophic conditions, whereas these of Tomeas-6 suggest pure telmatic conditions. The $\mathrm{VI}$ values of the Notio-Field samples $(\mathrm{Vl}<1)$ indicate herbaceous vegetation origin. Herbaceous vegetation with presence of arboreal elements origin is proposed for Tomeas-6 lignite seam.

TPI vs. GI Diagramme (after Diessel 1992, modified)

VI vs. GWI Diagramme (after Calder et al. 1992, modified)
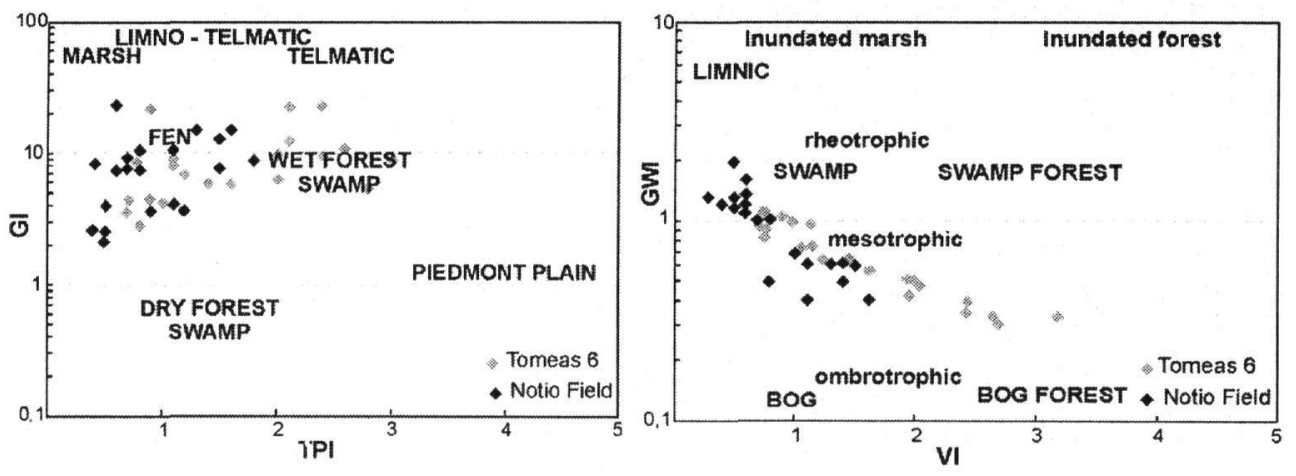

Facies diagramme (after Mukhopadhyay 1989)

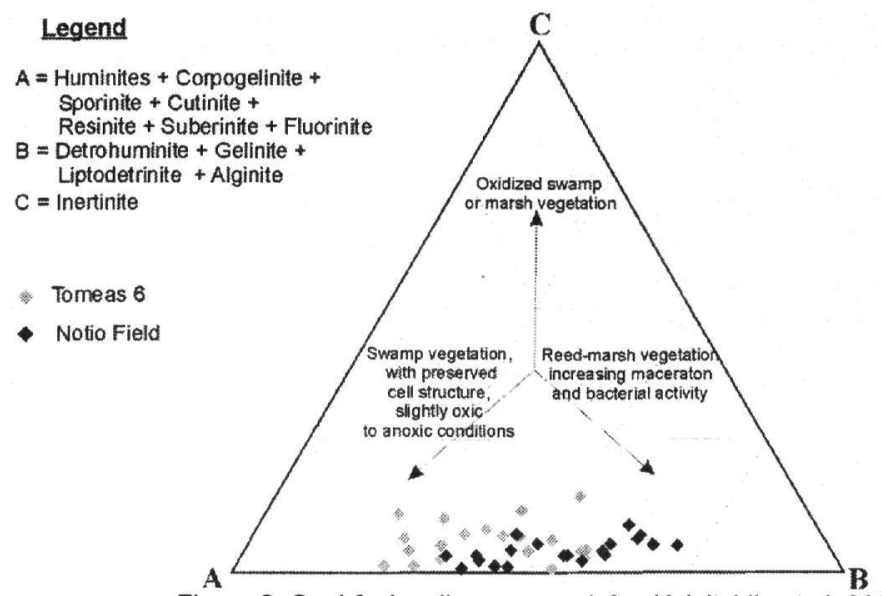

Figure 3. Coal-facies diagrammes (after Kalaitzidis et al. 2004). 


\section{CONCLUSIONS}

Lignite formation in the southern part of the Ptolemais Basin took place in Upper Miocene to Lower Pliocene through the terrestrialization of the previously existing lake, into which the Basal Marl deposited.

Peat accumulation features were slightly different in Notio-Field area than those dominated in Tomeas- 6 area. The former lake started terrestrializing from Tomeas- 6 towards Notio-Field area. Hence, at early stages peat accumulation at Tomeas 6 was established under limnotelmatic and later under pure telmatic habitats, whereas at Notio Field peat accumulated closer to the lake shore, under more saturated conditions. Peat-forming vegetation was mainly herbaceous, with arboreal elements present mostly at Tomeas 6 . As arboreal vegetation is more resistant to degradation, the organic matter was better preserved in Tomeas-6 Mine.

Seasonal fluctuations of groundwater table led to the enrichment of peat in inorganic matter, while extended flood events were interrupting peat formation, causing the deposition of inorganic layers. The groundwater table was generally high and prevented the oxidation of plant remnants. However, short-term periods of low groundwater table favoured the mechanical degradation of the herbaceous plant remnants.

Gradually, the palaesmire conditions turned to pure telmatic in the upper part of the studied profiles until peat formation was shortly interrupted from the deposition of the Volcanic Tephra Layer.

\section{REFERENCES}

American Society for Testing and Materials (A.S.T.M.) 1989. D3174. Ash in the analysis sample of coal and coke from coal. In: Annual book of ASTM Standards, Gaseous fuels: coal and coke, Philadelphia, Part 26, 291-294.

American Society for Testing and Materials (A.S.T.M.) 1989. D3302. Total moisture in coal. In: Annual book of ASTM Standards, Gaseous fuels: coal and coke, Philadelphia, Part 26, 326-332.

American Society for Testing and Materials (A.S.T.M.) 1990. D2797. Preparing coal samples for microscopical analysis by reflected light. In: Annual Book of ASTM Standards, Gaseous Fuels. Coals and Coke, Philadelphia, Part 26, 270-273.

Anastopoulos G.C. \& Koukouzas C.N. 1972. Economic geology of the Southern part of Ptolemais lignite Basin (Macedonia-Greece). Geol. Geoph. Res., XVI (1), 189p (in Greek).

Antoniadis P., Kaouras G., Khanaqa P.A. \& Riegel W. 1992. Petrographische Untersuchugen an der Neogen Braunkohle im Becken von Chomatero-Koroni. SW-Peloponess. Griechenland. Acta Palaeobot., 32/1, 2737.

Calder J., Gibling M. \& Mukhopadhyay P. 1991. Peat formation in a Westhalian B piedmont setting. Cumberland Basin. Nova Scotia. Bull. Soc. Geol. France., 162-2, 283-298.

Cameron A., Kalkreuth W. \& Koukouzas C.N. 1984. The petrology of Greek brown coals. Int. J. Coal Geol., 4, 173-207.

Diessel C. 1992. Coal-bearing depositional systems. Springer Verlag, Berlin, 721p.

Georgakopoulos A. \& Valceva S. 2000. Petrographic characteristics of Neogene lignites from the Ptolemais and Servia basins, Northern Greece. Energy Sources, 22, 587-602.

International Committee for Coal Petrology (I.C.C.P.) 1963. International Handbook of Coal Petrography, $2^{\text {nd }}$ edition. Centre National de la Recherche Scientifique, Paris, France.

International Committee for Coal Petrology (I.C.C.P.) 1971. International Handbook of Coal Petrography, $1^{\text {st }}$ supplement to $2^{\text {nd }}$ edition. Centre National de la Recherche Scientifique, Paris, France.

International Commitee for Coal Petrology (I.C.C.P.) 1993. International Handbook of Coal Petrography, $3^{\text {rd }}$ supplement to $2^{\text {nd }}$ edition. Centre National de la Recherche Scientifique, Paris, France.

International Commitee for Coal and Organic Petrology (I.C.C.P.) 2001. The new inertinite classification (I.C.C.P. System 1994). Fuel, 80, 459-471.

Kalaitzidis S., Bouzinos A. \& Christanis K. 1998. The depositional palaeoenvironment of the Upper Xylitic Horizon of the Ptolemais lignite deposit. Proc. $8^{\text {th }}$ Int. Geol. Congr., Patras, Greece, XXXII (2), 289-297 (In Greek with English abstract).

Kalaitzidis S., Bouzinos A. \& Christanis K. 2000. The lignite-forming palaeoenvironment before and after the deposition of the Volcanic Tephra Layer at the lignite deposit of Ptolemais Basin. Mineral Wealth, 115/2000, 29-42 (In Greek with English abstract).

Kalaitzidis S., Bouzinos A., Papazisimou S. \& Christanis K. 2004. A short-term establishment of forest fen habitat during Pliocene lignite formation in the Ptolemais Basin, NW Macedonia Greece. Int. J. Coal Geol., 57, 243-263. 
Kalaitzidis S. \& Christanis K. 2000. Petrography, mineralogy and geochemistry of the Holocene peat of the Philippi peatland, Hellas: Preliminary results. Sustaining our Peatlands. Proc. $11^{\text {th }}$ Int. Peat Congress, Quebec, Canada, vol. 2, 593-603.

Kalaitzidis S., Papazisimou S. \& Christanis K. 2001. Forming conditions of Graikas lignite, N. Peloponnese. Proc. $9^{\text {th }}$ Int. Geol. Congr., Athens, Greece, XXXIV (3), 1195-1204 (In Greek with English abstract).

Mukhopadhyay M. 1989. Organic petrography and organic geochemistry of Tertiary coals from Texas in relation to depositional environment and hydrocarbon generation. Report of Investigations, Bureau of Economic Geology, Texas, $118 \mathrm{p}$.

Kaouras G., Antoniadis P., Blickwede H. \& Riegel W. 1991. Petrographische und palynologische Untersuchungen an Braunkohlen im Becken von Drama, Ostmakedonien (Griechenland). N. Jb. Geol. Paläont. Mh., 3, 145-162.

Kilias A. \& Mountrakis D. :989. The Pelagonian Nappe, tectonics, metamorphism and magmatism. Bull. Geol. Soc. Greece, XXIII/1, 29-46 (in Greek with English abstract).

Papanicolaou C., Dehmer J. \& Fowler M. 2000. Petrological and organic geochemical characteristics of coal samples from Florina, Lava, Moschopotamos and Kalavryta coal fields, Greece. Int. J. Coal Geol., 44, $267-$ 292.

Pavlides S. \& Moutrakis D. 1987. Extensional tectonics of northwestern Macedonia, Greece, since the late Miocene. J. Struct. Geol., 9, 385-392.

Scott A.C. 2002. Coal petrology and the origin of coal macerals: a way ahead? Int. J. Coal Geol., 50, 119-134.

Steenbrick J. 2001. Orbital signatures in lacustrine sediments. The Late Neogene intramontane FlorinaPtolemais-Servia Basin, northwestern Greece. Mededelingen van de Faculteit Aarwetenschappen. Univ. Utrecht, No 205, 167p.

Sýkorová I., Pickel W., Christanis K., Wolf M., Taylor G.H. \& Flores D. (in prep.). Classification of Huminite I.C.C.P. System 1994.

Taylor G.H., Teichmüller M., Davis A., Diessel C.F.K., Littke R. \& Robert P. 1998. Organic Petrology. Gebrüder Borntraeger, Berlin-Stuttgart, 704. 